\title{
User Experience Design Practices in Industry (Case Study from Indonesian Information Technology Companies)
}

\author{
Isnan Nugraha ${ }^{1}$, Agung Fatwanto ${ }^{2 *}$ \\ ${ }_{1,2}^{1,2}$ agister of Informatics, Faculty of Science and Technology, Universitas Islam Negeri Sunan Kalijaga Yogyakarta \\ *E-mail: agung.fatwanto@uin-suka.ac.id
}

\begin{abstract}
User Experience (UX) is a term that has received a lot of attention in the last decade. The number of industries whose consider the importance of implementing the UX design process within their development cycle has increased. Therefore, we think it is important to investigate how UX design processes are implemented in the industries. In this research, we take a qualitative approach with descriptive methods by investigating six information technology companies in Indonesia. As a result, we found that most of these companies that sell services (apps) or have software-related ventures implement the UX design process as part of their operation and consider that the UX design process is an important part of software development. Each company has its order and priorities about the UX design processes and only follows their established UX design process framework to meet its product development requirements. We also found that there is different UX design process approaches from these six companies.
\end{abstract}

Keywords: user experience, UX, awareness, usability, industry

\section{INTRODUCTION}

UX (User Experience) has been a hot topic in recent years. There are so many new career titles that haven't yet been heard of five years ago [1]. UX Designer, UX Writer, UX Researcher, UX Architect, and other positions containing the word "UX" abound in job postings in Indonesia, especially in start-ups and IT firms.

What is UX and why has it recently gained popularity in the industry are UX-related issues. For a long time, UX has been implemented and widely debated in academic circles, and there have been several articles exploring the benefits and challenges of UX implementation in the industry [2]-[5]. The user interface (UI), according to some researchers, is one of the most influential aspects of providing a positive user experience [6]. As a result of convincing computing, interface design has emerged as one of the most important liberal arts of the twentyfirst century. It is critical to design appealing interfaces to have a positive user experience. Furthermore, in comparison to the past, the consumer interface and time-to-market components are now significantly higher [7]. UI and UX are often related to usability, as usability is a part of ISO/IEC 25010 (standard for software quality model) [8][9]. This is due to the fierce competition for existing goods.

User Experience is closely linked to the user-cantered principle, which is still commonly used in software development. The demands and preferences of end-users heavily affect software and product growth [10]. The UX Design Process is used to discover and develop usercantered software.

UX includes all the effects that appear before, during, and after using a product, system, or service (emotions, beliefs, behaviours, and user achievements) [11]. User Experience is composed of various dimensions [6]. For example, a thing can be said to have a good UX if it is easy to use, efficient, and additionally attractive, the joy of use and aesthetics [12].

Furthermore, a successful UX can increase job morale and boost user performance [13]. And their research findings indicate that this is critical for gaining a market share. The 
affordability feature of UX design is something that encourages or moves the user to do or experience something in UX design, where the key aim is to support users [14]. As a result, it is not shocking that UX is one of the emerging areas, with several major corporations focusing on it [15].

User Experience Design is design thinking that is applied to achieve the desired objectives. In this case a successful UX. An UX lifecycle method is a representation of how you order the lifecycle activities over time and how the lifecycle activities [16]. As shown in Figure 1 , the UX lifecycle is often replicated to achieve the best outcomes each time.

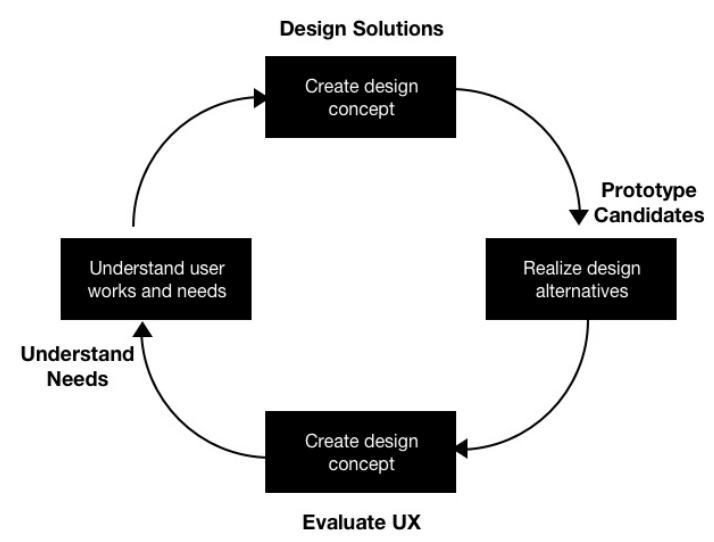

Figure 1. UX Design life cycle [16]

Many people believe that academic UX theory is so far removed from its use in the industrial world. There is a difference between how academia develops usability and UX processes, and its use in the industry has been a source of debate for decades [2]. This is because when applied according to academic standards, the UX Design Process is very long, complicated, and not ideally appropriate for all forms of software production. One of the causes for discrepancies in the UX Design Process academically and in the industry is the use of different software development approaches. In certain businesses, UX has also been a part of corporate policy and one of the pillars upon which decisions are taken [17].

So, what is the extent of UX Design experience in the industrial world? Is this finally completed? Since the practice has given more information about UX than the implementation of the UX model [5]. If so, does the use of UX Design have an effect on the products created? Is UX Design really important in the end? Through carrying out this research, we will be able to find answers to these issues.

Many studies have been conducted to determine how the industrial world employs UX Design and its effects. There are papers on article portals that address this.

In [2] Øvad and colleagues investigated the prevalence of UX Design in industries that use an Agile Development Process. This research was carried out in two phases over two years, the first in 2013 and the second in 2015. Their findings revealed that almost all businesses formed UX Strategy at the same time, using a more structured UX Process. In addition, there has been a substantial improvement in the allocation of resources for UX Design. This is associated with a greater appreciation of the significance of accessibility and better UX.

Furthermore, Lauesen [18] brought up the topic of Usability Engineering deployment in the industrial world. According to the findings of this study, Usability Techniques are rarely employed in industrial settings. There are several reasons for this, including 1 . Developers are worried about usability but are unsure how much they should do. They are unable to do it because they believe it is not worthwhile or that it is not their duty. 2 . There are no business expectations. Business demands are for functionality, and the market cannot devise compatibility requirements on its own. 3. Developers had trouble locating consumers for usability testing. When usability testing is completed, the developer is astounded at the number of issues discovered and is at a loss about what to do. 4. Developers believe that usability testing is similar to debugging, that is, repairing something after it goes wrong rather than developing something from the ground up.

Another research [19]. undertaken by Bygstad and colleagues discusses two disciplines that are critical in software development. Specifically, Software 
Development Methods (SDM) and compatibility, which are not widely used in industry. According to the findings of their study, there is a positive propensity in the industry to apply usability, but it is still far from the requirements. In addition, based on the results of the study, the company desires convergence of accessibility and product creation processes.

Da Silva and colleagues [20] performed theory-to-practice research on User Experience Design and Agile Development. Their analysis attempts to investigate the convergence between User Experienced Design and Agile Development. To see whether what is in theory, matches what is in reality or whether there is a difference between the two. Furthermore, they explain their theory that UX Designers cannot completely cooperate with developers because UX Designers are working on several projects at the same time, making them overburdened. As a result, they are unable to concentrate on the project under consideration.

Ardito and colleagues [4] investigated the industrial use of UX practice. As a result, most app engineers engage in little or no usability engineering. This study shows that many too many businesses choose to overlook accessibility and user experience (UX), or even ignore it entirely.

\section{METHOD}

This paper aims to identify the UX Design process in the industry (real world) and how it varies from theory. As a result, in 2020, we conducted interviews with six companies in Yogyakarta, Indonesia. This study was performed on many companies with various products or ventures, but all of them are associated with and or use the UX Design Process in their everyday lives.

This is a descriptive study. The descriptive analysis attempts to explain a phenomenon and its features. This research focuses on "what" rather than "how" or "why" something happens [21]. This study looks at current trends in everyday life [22]. All data is obtained by different parties and in various formats during its execution. This research would look at UX concept recognition in the industrial world. All data gathered will be based on locating data on the subject but will not be too general. As a result, it will stay focused on the study objectives.

The phases of the study are shown in the figure below.

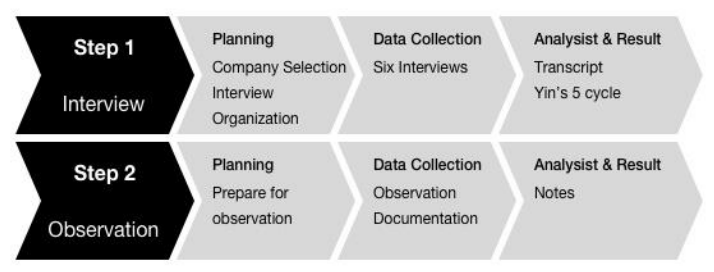

Figure 2. Research Stages

The purpose of this interview is to identify and map the following research questions:

1. Is the company aware of the concept of User Experience Design?

2. What is the company's level of familiarity with User Experience Design? What exactly are the forms?

3. What is the company's software development method?

4. What User Experience Design process steps do they do?

5. What products do you create in your office?

6. What factors influence UX Design decisions?

7. Why are you doing the UX Design process in your office? And are the findings in line with what was expected?

Any information about the backgrounds of UX professionals as well as how the organization sees UX would be requested.

\section{A. Interview}

The interviews were in-depth and semistructured. In-depth interviews were conducted to gather as much information about attitudes, knowledge and views of respondents towards the UX Design Process. And semi-structured interviews were conducted to make respondents more relaxed and comfortable, so they can provide the information freely. We were able to 
gather observational evidence from interviews of six interviewees from six different industries and backgrounds. They are both involved in the UX Design Process at their respective firms. To obtain more information from the interviewees, we attempted to use the "swim-along" approach during the interviews [23].

\section{B. Selection Criteria}

We chose the companies depending on multiple factors, including:

1. Firms that sell services (apps) or have software-related ventures.

2. Company scale as measured by the number of workers [6]

a. Small companies: $<50$

b. Medium enterprises: $<250$

c. Large companies: $>250$

3. The company is based in Yogyakarta, Indonesia.

4. Companies that do UX Design Process and are interested in UX.

5. The companies should operate for more than 2 years.

The following six businesses were discovered as a result of the selection:

Table 1. Overview of the Companies

\begin{tabular}{|l|l|c|}
\hline $\begin{array}{c}\text { Company } \\
\text { Name. }\end{array}$ & Company Type & Employee \\
\hline Company 1 & UI/UX Agency & 16 \\
\hline Company 2 & UI/UX Agency & 8 \\
\hline Company 3 & $\begin{array}{l}\text { Online } \\
\text { Marketplace }\end{array}$ & 150 \\
\hline Company 4 & Software House & 200 \\
\hline Company 5 & Software House & 40 \\
\hline Company 6 & Software House & 18 \\
\hline
\end{tabular}

\section{Interviewee Profiles}

Interviews were performed with the six interviewers mentioned below. The following table shows data from the interviewee's career history, qualifications, and experience in the interviewee industry:
Table 2. Interviewee

\begin{tabular}{|c|l|l|c|}
\hline $\begin{array}{c}\text { Inter } \\
\text { view } \\
\text { ee }\end{array}$ & Job & Education & Employee \\
\hline I1 & $\begin{array}{l}\text { Creative } \\
\text { Director }\end{array}$ & $\begin{array}{l}\text { Senior High } \\
\text { School }\end{array}$ & 8 years \\
\hline I2 & $\begin{array}{l}\text { Creative } \\
\text { Director }\end{array}$ & $\begin{array}{l}\text { Bachelor of } \\
\text { Arts }\end{array}$ & 10 years \\
\hline I3 & $\begin{array}{l}\text { UX } \\
\text { Designer }\end{array}$ & $\begin{array}{l}\text { Bachelor of } \\
\text { Design }\end{array}$ & 8 years \\
\hline I4 & $\begin{array}{l}\text { UI } \\
\text { Designer }\end{array}$ & $\begin{array}{l}\text { Bachelor of } \\
\text { Informatics } \\
\text { Engineering }\end{array}$ & 5 years \\
\hline I5 & $\begin{array}{l}\text { Lead UX } \\
\text { Designer }\end{array}$ & $\begin{array}{l}\text { Bachelor of } \\
\text { Communicati } \\
\text { on Science }\end{array}$ & 6 years \\
\hline I5 & $\begin{array}{l}\text { Product } \\
\text { Owner }\end{array}$ & $\begin{array}{l}\text { Bachelor of } \\
\text { Informatics } \\
\text { Engineering }\end{array}$ & 8 years \\
\hline
\end{tabular}

The top two lists are published as creative directors, but since the company is small, they also act as product managers and help in the design process.

\section{Procedures}

All interviews were conducted in Yogyakarta, Indonesia. Each interview took between 20 and 50 minutes. The interviews were conducted by a set of criteria, which included:

1. Company background. Their background includes everything about their business model and how they operate their business.

2. Awareness of UX Design. Are they aware or not of UX Design?

3. Software development methods. Which development methods they choose.

4. UX Design Process carried out

5. Products developed. What products that they create.

6. How decisions are made in the process of UX Design.

7. The purpose of carrying out the UX Design process

Firstly, we ask about the meaning of user experience to the company. After asking the mandatory questions based on the instructions 
above, the interview is continued by asking several more detailed questions based on the answers that have been obtained.

The interview transcript has been translated from Indonesian to English. The interview findings were analyzed using Yin's five-step cycles, which are compiling, disassembling, reassembling, translating, and concluding [22].

\section{E. Data Analysis}

The interviews were recorded and later transcribed into interview transcripts. The findings of the interview were analyzed and classified into some points depending on the similarities of interviewee's responses. This procedure is applied to the interview findings to generate data that can be quickly read. Then, to reinforce the evidence, direct quotes from the interviewees about the responses they provided during the interview would be included.

\section{F. Observation}

After collecting all of the evidence from the interview, we conducted observations in each location to double-check the accuracy of the information gathered from the interview. Furthermore, this observation was carried out to collect comparative data to improve or correct any flaws in the data gathered from interviews.

Observations on historical documents from each company should be made to reinforce existing data. It cannot, however, be achieved because it is a risk for the firm. As a result, to do UX design, we make observations about how each company completes its work.

\section{RESULTS AND DISCUSSION}

\section{A. Yin's Five Phases of Analysis}

To analyze the data, we use Yin's five phases of analysis like in the picture below. First phase is to compile database, and then disassemble data, reassemble data, interpret data and the last phase is conclude.

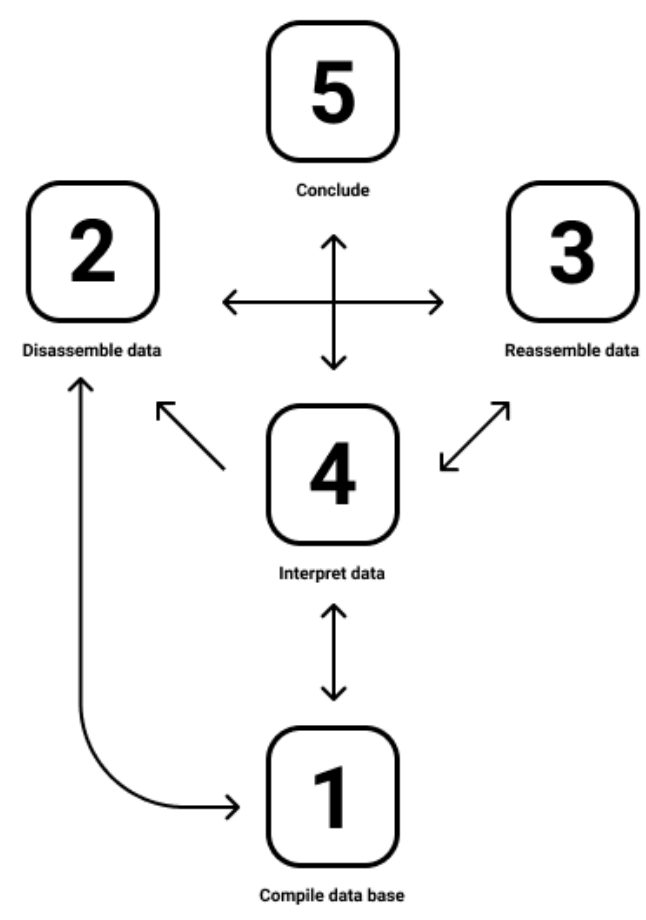

Figure 5. Yin's Five Phases of Analysis [24]

First, we compile the database. We collect all the information from interviews and find previous research (journals). And after that put all information to Nvivo for the next process.

Second, disassemble data. After collecting all the information and putting it all in Nvivo, we sort and code the data. All of the information is broken down into smaller fragments and code for every piece.

Third, reassemble data. After disassembled into fragments, we array the data into a list and from this phase. In this phase we can see the pattern of the data. And also, we can group every list of what we are looking for; for example awareness of UX design and form of awareness.

Fourth, interpret data. In this phase, we group all the data into tables and make sure that the data can be read easily.

After doing all the process, the next phase is conclude. We conclude all of the questions on this research based on the data we have collected and analyzed from four phases before. 


\section{B. Awareness of UX Design}

First, we inquired of the interviewees about the company's perspective on the UX Design Process, whether or not they are aware of it. This is a crucial topic to raise at the beginning before answering follow-up questions and it relates to how the organization sees the value of using the UX Design Process.

Based on the interview, we classified their answers into 3 criteria's; aware, maybe, and not aware of UX design. The results of the interview are as follows:

Table 3. Awareness of User Experience Design

\begin{tabular}{|l|c|}
\hline \multicolumn{1}{|c|}{ Strategy } & \% of all companies \\
\hline Aware & $84 \%$ \\
\hline Maybe & $16 \%$ \\
\hline Not Aware & $0 \%$ \\
\hline
\end{tabular}

The majority of companies (5 out of 6) tend to be aware of the UX Design Process. The rest of the companies (1 company) said they might be aware. This indicates that the majority of IT companies, especially in Indonesia, are becoming more aware of the UX Design Process. The high level of awareness of UX is enough to demonstrate that the study of UX is no longer just a product of academic research but is also being used as a guide in the industrial world, especially in Indonesia.

Furthermore, after this question was asked, the authors followed up with questions about how the company created awareness of the UX Design process.

The only one who responded maybe, the I6 mentioned that "Maybe, our form of awareness sometimes accommodates requests for overview changes from clients; there are no specific employees for UX Design; at our company, the front-end developer is also doing $U X$ design." Hence, in the only company that gives a response, they revealed that there are no special people or staff who handle UX design. It is only done by UI designers who are also UX designers.

\section{Form of Awareness}

After making observations, the results of the observations indicate that basically, almost all companies are aware. They are interested in what UX design is and have proven for themselves the difference between thinking about UX design or not. However, the level of awareness varies. Some prepare special resources, some are not. However, some are unaware because customer demands do not always imply that an in-depth UX study is required. This is due to tight deadlines and more emphasis on functionality. Furthermore, some clients, such as the government, are unfamiliar with things like UX and things that are technical.

The next step is the awareness of UX Design. Each interviewee company was asked about their level of awareness of the UX Design Process. This is to see if these companies are aware of the issue or if they are just answering questions. And based on their answers about the shape of awareness to UX design, we classified it into 2 criteria's; have specific resources of UX and do UX design process. The following are the outcomes:

Table 4. The shape of Awareness to UX Design

\begin{tabular}{|l|c|}
\hline \multicolumn{1}{|c|}{ Shape of Awareness } & $\%$ of all companies \\
\hline $\begin{array}{l}\text { Have specific resources of } \\
\text { UX / UX Team / UX } \\
\text { Designer }\end{array}$ & $33 \%$ \\
\hline Doing UX design process & $84 \%$ \\
\hline
\end{tabular}

Based on the responses, we divide the form of awareness into two parts. The first has a designated UX resource, while the second manages the UX Design Process. According to the results of the interviews, two out of six companies had special resources for UX. These companies have their own dedicated UX team that is responsible for the UX of the products they create. Some of the others (5 out of 6 companies) do not have their resources. The person in charge of UX in a software house is usually also the UI Designer or Front-End 
Engineer. Meanwhile, the person in charge of UX at the UX Agency is also the UI Designer.

[Company 5] is one of the few that has its UX team. I5 said that "If the resources allocated for now are in the product team. For the UX team itself, there are only three people who are officially part of the UX team, with one apprentice. The first is that I have a UX lead, two $U X$ designers, and one UX researcher." They assign 5 special people to work on UX design, with each person having their own set of tasks.

Apart from [Company 5], [Company 3] is a company that also has its resources for UX design.

The next results show that as many as 5 out of 6 companies adopt the UX Design Process properly. Although most companies have their formula for adopting the UX Design Process in practice. There is one company that does not implement the UX Design Process because of personnel limitations. Furthermore, the project's requirements do not require a good UX as they are more concerned with functionality.

These two facts are sufficient to demonstrate that the level of UX Design awareness in Indonesian companies is currently quite high. It has been proven that companies using the UX Design process surpass those who do not. Even though only a small percentage of them have their resources, most of them are still handled by the UI Designer or Front-End Engineer.

\section{Software Development Method Implemented in Company}

Next is the software development method used by the company. The UX Design Process is highly influenced by the software development method used. Different methods would have an impact on how decisions are taken when the UX Design Process is completed, and which processes are completed during the UX Design Process. This is because the UX design process must be adaptable and adhere to software development practices, which can be thought of as a general overview of how the software will be created. After all, the UX Design Process is included.

Table 5. Development Framework Used

\begin{tabular}{|l|c|}
\hline Development Framework & \% of all companies \\
\hline Waterfall & $16 \%$ \\
\hline Scrum + Waterfall & $0 \%$ \\
\hline Agile & $67 \%$ \\
\hline Ad Hoc & $16 \%$ \\
\hline
\end{tabular}

Based on the results of interviews, as many as 4 out of 6 or $67 \%$ of the sample used the Agile method, indicating that most of them used the Scrum model. In the meantime, one sample utilizes a waterfall, another utilizes Agile, and the last is Ad Hoc (changing according to the method used by the client). [Company 1] is the one that uses the Ad Hoc method because it adapts to the needs of the client rather than using only one method.

Why do most people use Scrum? Several interviewees answered that Scrum is easier to use at the scale of the company they work for, besides being more free and comfortable [25]. This is in line with research findings that Agile, which was once thought to be just for developers, is now becoming popular and significant for organizations in general, as well as the UX world [26], [27]. Furthermore, Agile UX designers will carry out the tasks during the user research and testing stages [28].

\section{UX Design Process}

Table 6. UX Design Process Formulation

\begin{tabular}{|l|c|}
\hline \multicolumn{1}{|c|}{ UX Design Process } & $\%$ of all companies \\
\hline Ad Hoc & $50 \%$ \\
\hline Are developing process & $0 \%$ \\
\hline Have process & $33 \%$ \\
\hline $\begin{array}{l}\text { Not using UX design } \\
\text { process }\end{array}$ & $16 \%$ \\
\hline
\end{tabular}

Five out of six interviewee companies used the UX procedure, while the other did not. In addition, $60 \%$ of the interviewee companies carry out the UX process in an Ad Hoc manner (changing according to the method used by the 
client) and $40 \%$ already have a standard process. Since the time provided by the client is often very limited, the majority of interviewee companies use Ad Hoc.

Furthermore, there is one company that does not use the UX process at all because they confess to being less aware of the process from the beginning. This is supported by the findings of observations, which demonstrate that what is being done is not classified as a UX process.

\section{E. Usability and UX Methods implemented in Company}

After we analyzed the interview, we found that we can classify every usability and UX method every company does. We classify it into 7 criteria's; Lo-fi prototyping, usability testing, workshop, personas, expert evaluation, user or customer journey and user task analysis.

Each company follows a similar pattern, but with different application methods. Lo-fi prototyping was used by 66 percent of respondents. This is normally the first move that designers take. Other companies, on the other hand, skip this step and go straight to hi-fi prototyping, which is faster and more effective for clients. Furthermore, $66 \%$ performed usability testing, 50\% held workshops, and 33\% developed user personas.

In addition, it was found that only 1 company used user-task analysis and expert assessment.

Table 7. UX Design Process Used

\begin{tabular}{|l|c|}
\hline \multicolumn{1}{|c|}{ Method } & $\%$ of all companies \\
\hline $\begin{array}{l}\text { Lo-fi prototyping } \\
\text { (including sketching and } \\
\text { mock-ups) }\end{array}$ & $66 \%$ \\
\hline $\begin{array}{l}\text { Usability testing } \\
\text { (including think aloud and } \\
\text { IDA) }\end{array}$ & $66 \%$ \\
\hline $\begin{array}{l}\text { Workshop (doing } \\
\text { workshop to brainstorm } \\
\text { and gather ideas) }\end{array}$ & $50 \%$ \\
\hline $\begin{array}{l}\text { Personas (using personas } \\
\text { as a tool to define what } \\
\text { user needs and wants) }\end{array}$ & $33 \%$ \\
\hline
\end{tabular}

\begin{tabular}{|l|c|}
\hline $\begin{array}{l}\text { Expert evaluation (UX } \\
\text { expert evaluate the } \\
\text { product) }\end{array}$ & $16 \%$ \\
\hline $\begin{array}{l}\text { User or customer journey } \\
\text { (doing a test on real user } \\
\text { to complete a certain task) }\end{array}$ & $50 \%$ \\
\hline $\begin{array}{l}\text { User task analysis } \\
\text { (analyze data from the } \\
\text { test) }\end{array}$ & $16 \%$ \\
\hline
\end{tabular}

After making observations, what was said in the interview is true. They prefer lo-fi prototyping as it is the simplest, fastest, and easiest step.

Moreover, many companies often conduct usability testing because they believe that testing a product with a scenario gets results that are quite close to reality.

Almost all interviewees answered that there is no different treatment for different projects or products. The average follows the same stages and development methods as the others. There was one interviewee who responded "slightly different" because there was a discrepancy, but it was not significant.

\section{F. Different UX Design Process Approach to Different Type of Project}

Based on the interview, we can classify their answers into 3 criteria: same, very different and slightly different.

Table 8. Difference Treatment for Project and Product

\begin{tabular}{|l|c|}
\hline \multicolumn{1}{|c|}{ Treatment } & \% of all companies \\
\hline Same & $84 \%$ \\
\hline Very Different & $0 \%$ \\
\hline Slightly different & $16 \%$ \\
\hline
\end{tabular}

Almost all interviewees answered that there is no different treatment for different projects or products. The average follows the same stages and development methods as the others. There was one interviewee who responded "slightly different" because there was a discrepancy, but it was not significant. 


\section{G. How Decisions are Made}

In most companies, decisions are made depending on a bunch of different key figures [12]. The next step is to consider how decisions are taken.

Based on the interview, we classify their answers into 4 criteria: experience, experience + test, experience + test + theory, and experience + theory.

As many as $32 \%$ admitted based on experience, $16 \%$ based on experience and tests, $16 \%$ based on experience, tests, and theories, and $32 \%$ based on experience and theory. Therefore, to strengthen their decisions, all companies rely on experience, which is supplemented with reinforcement in the form of tests and theories.

Table 9. How Decision about UX Design is Made

\begin{tabular}{|l|c|}
\hline \multicolumn{1}{|c|}{ Strategy } & $\%$ of all companies \\
\hline Experience & $32 \%$ \\
\hline Experience + Test & $16 \%$ \\
\hline $\begin{array}{l}\text { Experience + Test + } \\
\text { Theory }\end{array}$ & $16 \%$ \\
\hline Experience + Theory & $32 \%$ \\
\hline
\end{tabular}

\section{H. The Purpose of Implementing UX Design Process and its Result}

The following are the outcomes of the UX Design process. The majority of respondents (5 out of 6) said it met their needs, while another one said it did not.

Table 10. The Result of Using UX Design

\begin{tabular}{|l|c|}
\hline \multicolumn{1}{|c|}{ Result } & $\%$ of all companies \\
\hline As Expected & $84 \%$ \\
\hline Not as Expected & $16 \%$ \\
\hline
\end{tabular}

There is only one company that responded under their expectations, "Our mission is to make the applications we develop, both projects and products, easier to understand and to operate, and to offer a better impression. Currently, several shortcomings do not meet our expectations." They assume that their use of the
UX design process is still inefficient and has failed to meet their objectives.

\section{Observations}

After which, as a comparison of the data obtained from the interview results, we make observations on the implementation of UX design in each company. The data that was successfully obtained from each company is listed below.

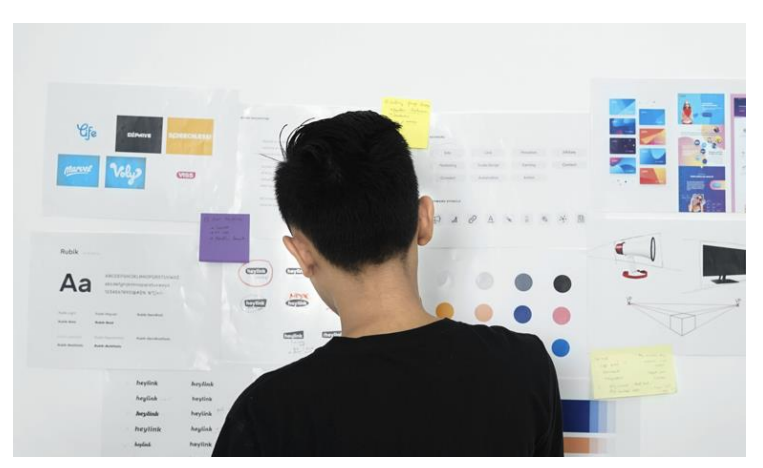

Figure 5. Brainstorming at [Company 1]

[Company 1], according to observations, performs the following UX design stages: lo-fi prototyping, hi-fi prototyping, and usability testing. Everything that was said in the interview turned out to be similar to what was done on the field. However, as stated in the interview, the process may vary depending on the needs of the software being developed or client orders.

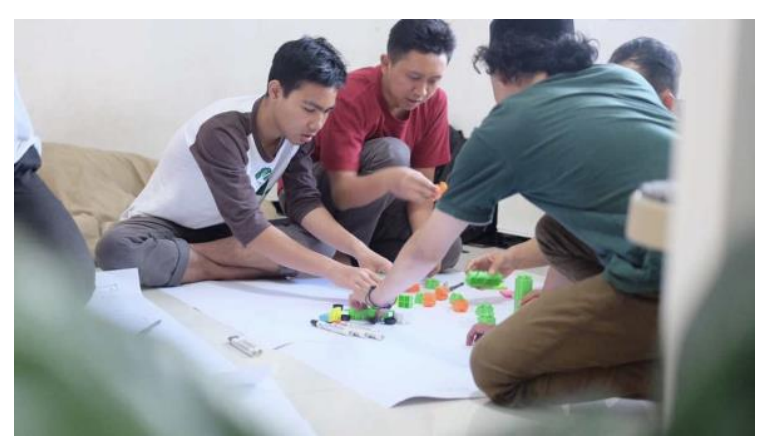

Figure 4. Lo-fi prototyping at [Company 2]

Observations at [Company 2] reveal that they also conduct UX design stages that are tailored to their specifications. Lo-fi prototyping, hi-fi prototyping, usability testing, and the user or customer journey are the steps taken. The 
actions taken correspond to what the interviewee said during the interview.

The results of observations at [Company 3] show that UX design is also very much considered here and has become part of the company culture. Lo-fi prototyping, usability testing, workshops, and personas are among the stages that were accomplished. Everything was based on the information provided by the interviewee.

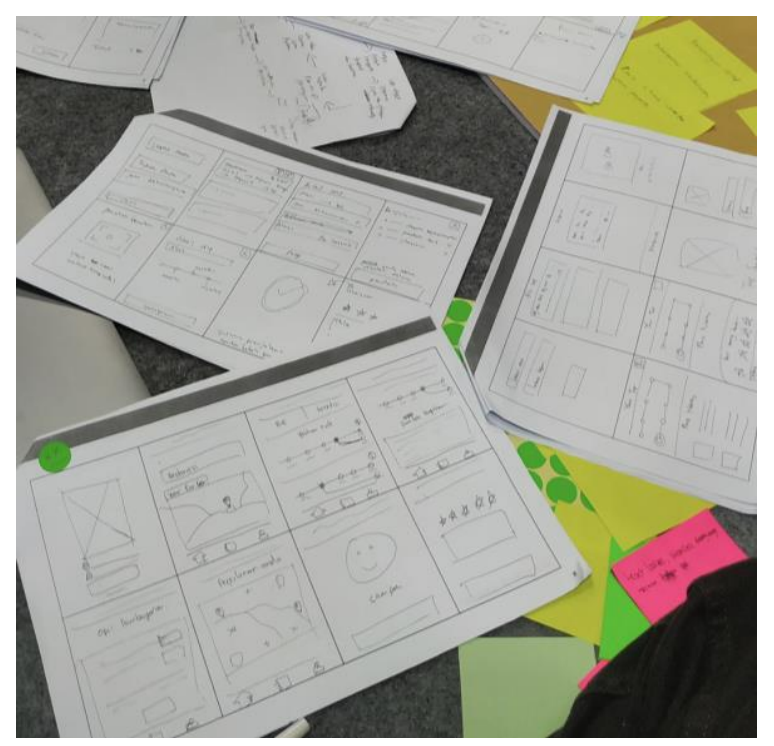

Figure 3. Lo-fi prototyping in [Company 4]

The results of observations on [Company 4] indicate that they carry out UX design stages that are customized to their specifications. As previously mentioned in the interview. Lo-fi prototyping, hi-fi prototyping, development, and user task analysis are the steps taken. During the interview, the interviewees said that they did not do lo-fi prototyping, but upon closer examination, it was discovered that they were. Only certain processes are carried out that they think are essential to save time and delivery of the products made.

The findings of the observations in [Company 5] indicate that UX design is taken seriously and becomes the main focus. As shown by the existence of a specialized UX team in charge of the [Company 5] products UX, including the website and dashboard. This team does Lo-fi prototyping, usability testing, workshops, personas, user or customer journey, and user task analysis to make sure that their products have a good User Experience. Both processes are carefully performed to obtain data that can later be used to make decisions.

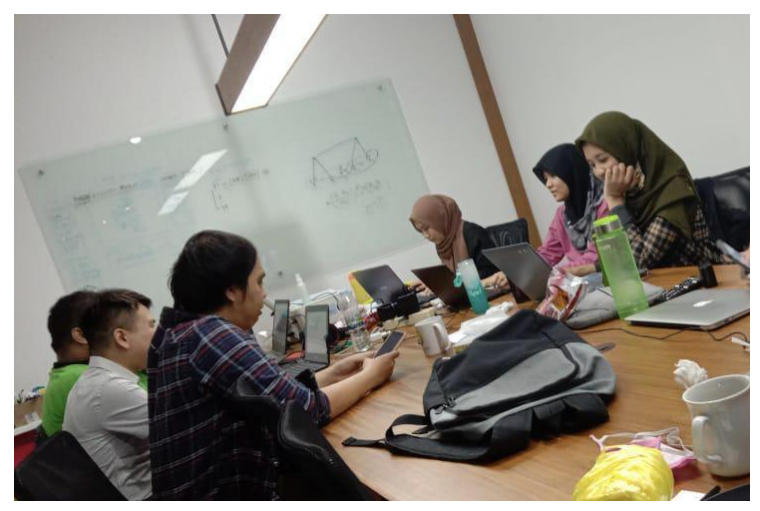

Figure 6. Brainstorming in [Company 6]

The observations of [Company 6] indicate that UX design is still receiving insufficient attention because there is no special treatment given to UX design research. There is no special personnel assigned to do this. This is also consistent with the results of interviews with interviewees from the data who answered "maybe".

\section{CONCLUSION}

According to the findings, it can be inferred that these six IT companies acknowledge that they are aware of UX Design. However, each company has different ways of performing the UX design process. A small number of companies manifest their awareness of UX Design by forming a special UX design unit within their enterprise. Whereas most of the companies did not go that far, rather they only implement a portion of UX design processes within their product development cycles.

All of the implementation types of the UX design process found in this study are part of a specific software development model which is implemented by each of these six IT companies. Among these six IT companies, agile is the most popular software development model. As a result, it requires a software development model 
that is dynamic. However, some companies would prefer waterfalls in order to comply with their client's requirement, while most other companies prefer Scrum because of its focus on high performance in each sprint. Furthermore, scrum offers more obvious insight that UX is not only the responsibility of the UX designer but also the entire team [13].

Each company has a different interpretation in regard to the UX Design process that they performed. But all of them have the same goal, namely to achieve good product results in terms of user experience. Each company also has different support for the UX design process implementation within their product development cycle. This kind of support is tailored to each company's specific needs.

When it comes to decision-making in the context of the UX design process, each company has its own strategies. [Company 3] and [Company 5] hold the stance that decisions must be taken based on test results data. Some companies, on the other hand, are more flexible, making decisions based on the needs of their clients.

Overall, only one company feels that the UX Design process did not meet their expectations. However, most companies feel they were satisfied with the progress and the results obtained through the implementation of the UX Design process.

\section{ACKNOWLEDGEMENT}

This research could not have been carried out without the support of the following companies, including Privy ID, Niagahoster, Ralali, Sebo Studio, Omnicreativora Studio and Datains. Thanks a lot for the help.

\section{REFERENCES}

[1] G. T. Yargın, S. Süner, and A. Günay, "Modelling User Experience: Integrating User Experience Research Into Design Education," p. 10, 2018.

[2] T. Ovad and L. B. Larsen, "The Prevalence of UX Design in Agile Development Processes in
Industry," in 2015 Agile Conference, National Harbor, MD, USA, Aug. 2015, pp. 40-49. doi: 10.1109/Agile.2015.13.

[3] W. Xu, "User Experience Design: Beyond User Interface Design and Usability," in Ergonomics - A Systems Approach, I. L. Nunes, Ed. InTech, 2012. doi: $10.5772 / 35041$.

[4] C. Ardito, P. Buono, D. Caivano, M. F. Costabile, and R. Lanzilotti, "Investigating and promoting UX practice in industry: An experimental study," Int. J. Hum.-Comput. Stud., vol. 72, no. 6, pp. 542-551, Jun. 2014, doi: 10.1016/j.ijhcs.2013.10.004.

[5] L. A. M. Zaina, H. Sharp, and L. Barroca, "UX information in the daily work of an agile team: A distributed cognition analysis," Int. J. Hum.Comput. Stud., vol. 147, p. 102574, Mar. 2021, doi: 10.1016/j.ijhcs.2020.102574.

[6] D. Saffer, Designing for interaction: creating innovative applications and devices, 2nd ed. Berkeley, CA: New Riders, 2010.

[7] M. L. Wong, C. W. Khong, and H. Thwaites, "Applied UX and UCD Design Process in Interface Design," Procedia - Soc. Behav. Sci., vol. 51, pp. 703-708, 2012, doi: 10.1016/j.sbspro.2012.08.228.

[8] R. D. Jayanto, "EVALUASI KUALITAS APLIKASI MOBILE KAMUS ISTILAH JARINGAN PADA PLATFORM ANDROID DENGAN STANDAR ISO/IEC 25010," Elinvo Electron. Inform. Vocat. Educ., vol. 2, no. 2, pp. 178-182, Dec. 2017, doi: 10.21831/elinvo.v2i2.17311.

[9] T. A. Ghaffur, "ANALISIS KUALITAS SISTEM INFORMASI KEGIATAN SEKOLAH BERBASIS MOBILE WEB DI SMK NEGERI 2 YOGYAKARTA," Elinvo Electron. Inform. Vocat. Educ., vol. 2, no. 1, pp. 94-101, Oct. 2017, doi: 10.21831/elinvo.v2i1.16426.

[10] L. C. Yee, J. Grundy, K. von Baggo, A. Cain, and R. Vasa, "Evaluating an Open Learner Model Visualisation Prototype Tool with User eXperience Metrics," in 2018 25th Australasian Software Engineering Conference (ASWEC), Adelaide, SA, Nov. 2018, pp. 51-60. doi: 10.1109/ASWEC.2018.00015.

[11] "ISO 9241-210:2019(en), Ergonomics of human-system interaction - Part 210: Humancentred design for interactive systems." https://www.iso.org/obp/ui/\#iso:std:iso:9241:210:ed-2:v1:en (accessed Apr. 21, 2021).

[12] A. Hinderks, M. Schrepp, F. J. Domínguez Mayo, M. J. Escalona, and J. Thomaschewski, "Developing a UX KPI based on the user experience questionnaire," Comput. Stand. Interfaces, vol. 65, pp. 38-44, Jul. 2019, doi: 10.1016/j.csi.2019.01.007. 
[13] P. Kashfi, R. Feldt, and A. Nilsson, "Integrating UX principles and practices into software development organizations: A case study of influencing events," J. Syst. Softw., vol. 154, pp. 37-58, Aug. 2019, doi: 10.1016/j.jss.2019.03.066.

[14] R. Hartson and P. Pyla, "Affordances in UX Design," in The UX Book, Elsevier, 2019, pp. 651-693. doi: 10.1016/B978-0-12-8053423.00030-8.

[15] M. Holstein, "User Experience Design," in iPhone App Design for Entrepreneurs, Berkeley, CA: Apress, 2019, pp. 59-74. doi: 10.1007/9781-4842-4285-8_7.

[16] R. Hartson and P. Pyla, "The Wheel: UX Processes, Lifecycles, Methods, and Techniques," in The UX Book, Elsevier, 2019, pp. 27-48. doi: 10.1016/B978-0-12-8053423.00002-3.

[17] D. Sward and G. Macarthur, "Making The User Experience a Business Strategy," presented at the Proceedings of HCI 2007 The 21st British HCI Group Annual Conference University of Lancaster, UK, Sep. 2007. doi: 10.14236/ewic/HCI2007.95.

[18] S. Lauesen, "Usability Engineering in Industrial Practice," in Human-Computer Interaction INTERACT '97, S. Howard, J. Hammond, and G. Lindgaard, Eds. Boston, MA: Springer US, 1997, pp. 15-22. doi: 10.1007/978-0-38735175-9_4.

[19] B. Bygstad, G. Ghinea, and E. Brevik, "Software development methods and usability: Perspectives from a survey in the software industry in Norway," Interact. Comput., vol. 20, no. 3, pp. 375-385, May 2008, doi: 10.1016/j.intcom.2007.12.001.

[20] T. Silva da Silva, M. Selbach Silveira, F. Maurer, and T. Hellmann, "User Experience Design and Agile Development: From Theory to Practice," J. Softw. Eng. Appl., vol. 05, no. 10, pp. $743-$ 751, 2012, doi: 10.4236/jsea.2012.510087.

[21] H. Nassaji, "Qualitative and descriptive research: Data type versus data analysis," Lang. Teach. Res., vol. 19, no. 2, pp. 129-132, Mar. 2015, doi: 10.1177/1362168815572747.

[22] R. K. Yin, "The Case Study as a Serious Research Strategy," p. 18.

[23] H. Denton, C. Dannreuther, and K. Aranda, "Researching at sea: Exploring the 'swim-along' interview method.," Health Place, vol. 67, p. 102466, Jan. 2021, doi: 10.1016/j.healthplace.2020.102466.

[24] R. K. Yin, Qualitative research from start to finish. New York: Guilford Press, 2011.

[25] A. Ananjeva, J. S. Persson, and A. Bruun, "Integrating UX work with agile development through user stories: An action research study in a small software company," J. Syst. Softw., vol.
170, p. 110785, Dec. 2020, doi: 10.1016/j.jss.2020.110785.

[26] J. S. Persson, A. Bruun, and P. A. Nielsen, "Agility for UX and Development: A Case Study," p. 7.

[27] J. Ferreira, H. Sharp, and H. Robinson, "User experience design and agile development: managing cooperation through articulation work," Softw. Pract. Exp., vol. 41, no. 9, pp. 963-974, Aug. 2011, doi: 10.1002/spe.1012.

[28] M. Najafi and L. Toyoshiba, "Two Case Studies of User Experience Design and Agile Development," p. 6. 